\title{
PERBEDAAN EFEKTIVITAS MENGUNYAH BUAH APEL DAN BUAH SEMANGKA DALAM MENURUNKAN NILAI DEBRIS INDEKS
}

\section{DIFFERENCES IN THE EFFECTIVENESS OF CHEWING APPLES AND WATERMELON FRUIT IN REDUCING THE VALUE OF DEBRIS INDEKS}

\author{
Niko Arinda Putri Diyatama ${ }^{1^{*}}$, Bambang Hadi Sugito $^{2}$, Isnanto $^{3}$ \\ 1,2, 3 Jurusan Keperawatan Gigi Politeknik Kesehatan Kemenkes Surabaya \\ Email : arindadiyatama@gmail.com
}

\begin{tabular}{|c|c|}
\hline & ABSTRAK \\
\hline & $\begin{array}{l}\text { Gigi dan mulut bagian penting dalam tubuh manusia. Agar dapat } \\
\text { menjalankan fungsinya dengan baik, kesehatan gigi dan mulut } \\
\text { perlu diperhatikan. Salah satu masalah kesehatan gigi dan mulut }\end{array}$ \\
\hline \multirow{8}{*}{$\begin{array}{l}\text { Kata kunci: } \\
\text { Apel } \\
\text { Semangka } \\
\text { Debris Indeks }\end{array}$} & pada siswa SMP Miftahul Ulum Surabaya adalah tingginya nilai \\
\hline & debris indeks, berdasarkan data pemeriksaan debris indeks \\
\hline & menunjukkan bahwa rata-rata debris indeks sebesar 1.94 yang \\
\hline & $\begin{array}{l}\text { termasuk dalam katagori buruk. Debris tidak dapat dibersihkan } \\
\text { dengan berkumur, debris dapat dibersihkan secara mekanis yaitu } \\
\text { self cleansing, dilakukan dengan mengunyah buah yang } \\
\text { mengandung banyak serat dan air, salah satunya buah apel dan } \\
\text { buah semangka. Tujuan dari penelitian ini untuk mengetahui } \\
\text { perbedaan efektivitas mengunyah buah apel dan buah semangka } \\
\text { dalam menurunkan nilai debris indeks pada siswa kelas VII SMP }\end{array}$ \\
\hline & $\begin{array}{l}\text { Miftahul Ulum Surabaya. Jenis penelitian ini menggunakan } \\
\text { penelitian Quasi Eksperimen (Eksperien Semu) pre-test dan post- } \\
\text { test, jumlah sampel dalam penelitian ini sebanyak } 32 \text { siswa kelas }\end{array}$ \\
\hline & $\begin{array}{l}\text { VII, pengambilan responden dengan cara membagi menjadi } 2 \\
\text { kelompok terdiri dari } 16 \text { siswa mengunyah buah apel dan } 16 \\
\text { siswa lainnya mengunyah buah semangka. Pengumpulan data } \\
\text { diperoleh dengan cara pemeriksaan langsung, dilakukan dengan } \\
\text { mengukur kebersihan gigi dan mulut menggunakan metode }\end{array}$ \\
\hline & $\begin{array}{l}\text { Debris Indeks. Hasil penelitian ini adalah analisis data } \\
\text { menggunakan uji independent sample T-test dengan nilai } \\
\text { signifikan } p=0,007 \quad(\mathrm{p}<0,05) \text { artinya mengunyah buah apel dan } \\
\text { buah semangka terdapat perbedaan efektivitas dalam } \\
\text { menurunkan nilai Debris Indeks. Sehingga buah semangka } \\
\text { adalah buah yang lebih efektif dalam menurunkan nilai debris } \\
\text { indeks. }\end{array}$ \\
\hline & ABSTRACT \\
\hline \multirow{4}{*}{$\begin{array}{l}\text { Key word: } \\
\text { Apple fruit } \\
\text { Watermelon } \\
\text { Debris Indeks }\end{array}$} & Teeth and mouth are important parts of the human body. In order \\
\hline & to carry out its functions properly, oral health needs to be \\
\hline & considered. One of the oral and dental health problems for \\
\hline & Miftahul Ulum Surabaya Middle School students is the high \\
\hline
\end{tabular}


value of the index debris, based on the index debris examination data, it shows that the average index debris of 1.94 is included in the bad category. Debris cannot be cleaned by gargling, debris can be cleaned mechanically, that is self cleansing, done by chewing fruits that contain lots of fiber and water, one of them is apples and watermelons. The purpose of this study was to determine differences in the effectiveness of chewing apples and watermelons in reducing the value of index debris in grade VII students of Miftahul Ulum Middle School Surabaya. This type of research uses a Quasi Experiment (Quasi Experimental) pre-test and post-test, the number of samples in this study were 32 grade VII students, taking respondents by dividing into 2 groups consisting of 16 students chewing apples and 16 other students chewing watermelon. Data collection was obtained by direct examination, carried out by measuring dental and oral hygiene using the Debris Index method. The results of this study are data analysis using independent sample T-test with a significant value of $\mathrm{p}=0.007 \quad(\mathrm{p}<0.05)$ meaning that chewing apples and watermelons there is a difference in effectiveness in reducing the Debris Index value. So that the watermelon is a fruit that is more effective in reducing the value of the index debris.

\section{PENDAHULUAN}

Gigi dan mulut merupakan bagian terpenting dalam tubuh manusia. Gigi terdapat dalam rongga mulut dan memiliki berbagai fungsi. Agar dapat menjalankan fungsinya dengan baik, kesehatan gigi dan mulut perlu diperhatikan. Keadaan gigi yang rusak dapat berdampak pada kesehatan tubuh lainnya dan berpengaruh pada estetik seseorang (Penda, 2015)

Data kesehatan gigi dan mulut nasional terlihat prevalensi nasional indeks DMF-T yaitu 4,6 lebih besar dari standar WHO 3,5. Karies merupakan salah satu bukti tidak terawatnya kondisi gigi dan mulut masyarakat. Fakta lainnya adalah karies orang Indonesia bersifat agresif kumulatif (Prasetiowati, 2016) Data indeks OHI-S masyarakat Indonesia rata-rata adalah 1,46 sedangkan indikator untuk indeks OHIS dengan kategori rendah $\leq$ 1,2. Data DMF-T dan OHIS diatas menggambarkan bahwa penyakit gigi dan mulut di Indonesia masih tinggi (Prasetiowati, 2016)

Banyak upaya yang dilakukan untuk menjaga kesehatan gigi dan mulut diantaranya dengan cara mekanik, chemis, dan modifikasi antara metode mekanik dan chemis. Salah satunya yaitu dengan cara menggosok gigi, flossing (menggunakan benang gigi), membersihkan lidah. Secara chemis yaitu menghindari makanan yang mengandung sukrosa, melainkan memperbanyak makan makanan berserat dan berair (Prasetiowati, 2016)

Makanan berserat dan berair bagus untuk kesehatan tubuh dan juga bagus untuk kesehatan gigi dan mulut. Berbagai macam buah dan sayur merupakan asupan yang aman untuk gigi. Buah dan sayur mengandung serat yang sangat efektif dan berfungsi sebagai pembersih gigi alami. Selain itu mengunyah buah dan sayur juga sangat baik untuk memberikan efek pemijatan pada gusi dan menyegarkan aroma mulut (Prasetiowati, 2016) Manfaat dari buah buahan yang lain adalah kemempuannya untuk dapat melakukan self cleansing terhadap rongga mulut. Makanan padat dan juga serat dari buah dan sayur secara 
fisiologis akan memaksa mulut manusia untuk menggerus dan menghancurkannya sebelum masuk ke saluran pencernaan selanjutnya, sehingga mendorong sekresi ludah.

Buah apel membantu membantu untuk merangsang gusi, meningkatkan aliran air liur di mulut dan mencegah penumpukan plak pada permukaan gigi. Kandungan dalam apel yang bermanfaat bagi kesehatan gigi dan mulut adalah tannin. Zat tannin ini merupakan zat yang berfungsi membersihkan dan menyegarkan mulut, sehingga dapat mencegah kerusakan gigi dan penyakit gusi yang disebabkan oleh plak (Nurasiki, 2017). Buah semangka merupakan buah yang berserat dan berair, dan memiliki kandungan air cukup banyak maka secara langsung dapat menghambat pembentukan plak pada gigi. Buah apel dan buah semangka termasuk salah satu buah berserat dan berair. Untuk pengunyahan buah ini memerlukan pengunyahan yang cukup sehingga dapat mendorong sekresi ludah. Sehingga buah apel dan buah semangka dapat membersihkan gigi dari sisa-sisa makanan secara alami.

Pemeriksaan siswa-siswi kelas VII SMP Miftahul Ulum Surabaya, diperoleh nilai debris indeks rata-rata 1,9. Bila dibandingkan dengan standart debris, hasil pemeriksaan menunjukkan bahwa nilai debris indeks rata-rata siswa-siswi kelas VII SMP Miftahul Ulum Surabaya berada dalam kategori jelek. Bila debris tersebut tidak dibersihkan maka akan mempengaruhi kesehatan gigi dan mulut yaitu antara lain karies, karies gigi adalah kerusakan jaringan keras gigi yang disebabkan oleh asam yang ada dalam karbohidrat melalui perantara mikroorganisme yang ada dalam saliva dan karang gigi karang gigi terbentuk dari dental plak yang mengeras pada gigi dan menetap dalam waktu yang lama. Dental plak merupakan tempat ideal bagi mikroorganisme mulut, karena terlindung dari pembersihan alami oleh lidah maupun saliva (Pratiwi, 2009) Dampak sosial dari debris yang tidak dibersihkan juga mempengaruhi bau mulut dan senyum juga tidak bagus jika ada debris yang menumpuk di dalam rongga mulut. Penetian ini bertujuan untuk mengetahui perbedaan efektivitas mengunyah buah apel dan buah semangka dalam menurunkan nilai debris indeks.

\section{METODE}

Jenis penelitian yang digunakanm adalah Penelitian Quasi Eksperimen (Eksperimen semu) pre-test dan post-test. Untuk membandingkan efektivitas mengunyah buah apel dan buah semangka pada siswa kelas VII SMP Miftahul Ulum Surabaya dengan siswa yang berjumlah 32. Metode pengumpulan data pada penelitian ini diperoleh dengan cara pemeriksaan langsung, dengan membagi dua kelompok yaitu kelompok mengunyah buah apel dan kelompok mengunyah buah semangka. Dilakukan dengan mengukur kebersihan gigi dan mulut menggunakan metode Debris Indeks. Pemeriksaan dilakukan pada gigi indeks 16, 11, 26, 36, 31, 46 dengan skor indeks debris yaitu, 0-1.2 = kategori baik, 0.7-1.8 = kategori sedang, 1.9-3 = kategori buruk. Setelah data terkumpul maka dilakukan pengolahan data dan untuk membuktikan data tersebut normal atau tidak yaitu dengan menggunakan Kolmogorov-Smirnov. Kemudian hipotesis diuji dengan menggunakan $T$ test untuk membandingkan perbedaan antar 2 kelompok. Uji yang akan digunakan adalah uji paired sample $T$ test untuk menghitung sebelum dan sesudah mengunyah buah, kemudian di uji menggunakan uji $\mathrm{T}$ tidak berpasangan (independent sample $T$ test) sehingga nantinya dapat diketahui apakah ada perbedaan antara mengunyah buah apel dan mengunyah buah semangka terhadap penurunan debris indeks. 


\section{HASIL DAN PEMBAHASAN}

Responden penelitian ini yaitu siswa kelas VII SMP Miftahul Ulum Surabaya dengan jumlah 32 siswa.

Tabel 1. Karateristik responden berdasarkan jenis kelamin

\begin{tabular}{ccc}
\hline Jenis kelamin & $\mathbf{N}$ & \% \\
\hline Laki-laki & 20 & 62,5 \\
Perempuan & 12 & 37,5 \\
Total & 32 & 100 \\
\hline
\end{tabular}

Karateristik responden berdasarkan jenis kelamin dapat dilihat pada tabel 1 yang menunjukkan responden penelitian berjenis kelamin laki-laki sebanyak 20 siswa, dan berjenis kelamin perempuan sebanyak 12 siswa.

Hasil penelitian pemeriksaan debris indeks dengan menggunakan cara perhitungan Green dan Vermilion. Pemeriksaan debris indeks dibagi menjadi empat yaitu pemeriksaan debris indeks sebelum mengunyah buah apel, kemudian pemeriksaan setelah mengunyah buah apel. Pemeriksaan sebelum mengunyah buah semangka, dan pemeriksaan sesudah mengunyah buah semangka.

Tabel 2. Hasil Pemeriksaan Debris Indeks sebelum mengunyah buah apel

\begin{tabular}{ccc}
\hline Kategori & $\mathbf{N}$ & $\mathbf{\%}$ \\
\hline Baik & 0 & 0 \\
Sedang & 5 & 31,2 \\
Buruk & 11 & 68,8 \\
Total & 16 & 100 \\
\hline
\end{tabular}

Data pada tabel 2 menunjukkan debris indeks sebelum mengunyah buah apel. Responden yang berada dalam kategori baik tidak ada (0\%), berada dalam kategori sedang 5 responden $(31,2 \%)$, dan yang berada dalam kategori buruk 11 responden $(68,8 \%)$.

Tabel 3. Hasil Pemeriksaan Debris Indeks setelah mengunyah buah apel

\begin{tabular}{ccc}
\hline Kategori & $\mathbf{N}$ & \% \\
\hline Baik & 2 & 12,5 \\
Sedang & 14 & 87,5 \\
Buruk & 0 & 0 \\
Total & 16 & 100 \\
\hline
\end{tabular}

Data pada tabel 3 menunjukkan debris indeks setelah mengunyah buah apel. Responden yang berada dalam kategori baik 2 responden $(12,5 \%)$, berada dalam kategori sedang 14 responden $(87,5 \%)$, dan yang berada dalam kategori buruk tidak ada $(0 \%)$. 
Tabel 4. Hasil pemeriksaan debris indeks sebelum mengunyah buah semangka

\begin{tabular}{ccc}
\hline Kategori & N & \% \\
\hline Baik & 0 & 0 \\
Sedang & 4 & 25 \\
Buruk & 12 & 75 \\
Total & 16 & 100 \\
\hline
\end{tabular}

Data pada tabel 4 menunjukkan debris indeks sebelum mengunyah buah semangka. Responden yang berada dalam kategori baik tidak ada ( $0 \%)$, berada dalam kategori sedang 4 responden (25\%), dan berada dalam kategori buruk 12 responden $(75 \%)$.

Tabel 5. Hasil pemeriksaan debris indeks setelah mengunyah buah semangka

\begin{tabular}{ccc}
\hline Kategori & N & \% \\
\hline Baik & 7 & 43,8 \\
Sedang & 9 & 56,2 \\
Buruk & 0 & 0 \\
Total & 16 & 100 \\
\hline
\end{tabular}

Data pada tabel 5 menunjukkan debris indeks setelah mengunyah buah semangka. Responden yang berada dalam kategori baik 7 responden $(43,8 \%)$, berada dalam kategori sedang 9 responden $(56,2 \%)$, dan berada dalam kategori buruk tidak ada $(0 \%)$.

Tabel 6. Hasil analisis Debris indeks sebelum dan sesudah mengunyah buah apel dan buah semangka

\begin{tabular}{cccccc}
\hline & Mean & & \\
\hline & Sebelum \pm s.d & Sesudah \pm s.d & $\begin{array}{c}\text { Sebelum } \\
\text { dan Sesudah } \\
\pm \text { s.d }\end{array}$ & $P$ Value \\
Menguyah Buah & 16 & $2.2 \pm 0.41$ & $1.2 \pm 0.29$ & $1.62 \pm 0.48$ & $<0.000$ \\
$\begin{array}{c}\text { Apel } \\
\text { Mengunyah Buah } \\
\text { Semangka }\end{array}$ & 16 & $2.4 \pm 0.45$ & $0.7 \pm 0.29$ & $1.90 \pm 0.55$ & $<0.000$ \\
\hline
\end{tabular}

Data pada tabel 6 menunjukkan debris indeks setelah mengunyah buah apel dan setelah mengunyah buah semangka. Dapat diketahui bahwa nilai mean sebelum mengunyah buah apel adalah 2.2 dengan standar deviasi 0.41 , nilai mean sesudah mengunyah buah apel adalah 1.2, dengan standar deviasi 0.29 dan mean sebelum dan sesudah mengunyah buah apel 1.62 dengan standar deviasi 0.48 dan $P$ value $<0.000$ ( $P$ Value $<0.05$ ) maka H1 diterima dan H0 ditolak artinya terdapat perbedaan debris indeks sebelum dan sesudah mengunyah buah apel. Sedangkan nilai mean sebelum mengunyah buah semangka adalah 2.4 dengan standar deviasi 0.45 , nilai mean sesudah mengunyah buah semangka adalah 0.7 dengan standart deviasi 0.29 , nilai mean sebelum dan sesudah mengunyah buah semangka adalah 1.90 dengan standar deviasi 0.55 dan $P$ value 0.000 ( $p$ value $<0.05$ ), maka $\mathrm{H} 1$ diterima dan $\mathrm{HO}$ ditolak yang artinya terdapat perbedaan debris indeks sebelum dan sesudah mengunyah buah semangka. 
Berdasarkan analisis data penelitian ini menunjukkan bahwa sebelum dan sesudah mengunyah buah apel memiliki perbedaan yang menunjukkan bahwa setelah mengunyah buah apel nilai debris indeks pada rongga mulut menjadi menurun, yang awalnya dengan katagori buruk menjadi sedang. Hasil penelitian ini sesuai dengan pernyataan Penda,dkk (2015) bahwa buah apel dapat menurunkan debris indeks secara efektif. Buah apel memiliki kandungan tannin berkonsentrasi tinggi yang dapat mencegah kerusakan gigi yang disebabkan oleh penumpukan plak. Kandungan serat pada buah apel dapat membantu membersihkan sisa-sisa makanan yang melekat pada gigi, karena apel merupakan buah berserat sehingga mengunyah buah apel bias disebut sebagai sikat gigi secara alamiah. Buah apel mengandung $84 \%$ air, serat 4 gram dan berbagai vitamin serta mineral. Buah apel kaya akan kandungan nutrisi yang bermanfaat bagi kesehatan. Selain itu buah ini membantu untuk merangsang gusi, meningkatkan aliran air liur di mulut dan mencegah penumpukan plak pada permukaan gigi (Agustini, 2015). Sedangkan sebelum dan sesudah mengunyah buah semangka memiliki perbedaan yang menunjukkan bahwa setelah mengunyah buah semangka nilai debris indeks pada rongga mulut menjadi menurun, yang awalnya dengan katagori buruk menjadi baik. Hasil penelitian ini sesuai dengan pernyataan Ratnasari (2016) menunjukkan mengunyah buah semangka juga mampu menurunkan debris secara signifikan. Penurunan ini terjadi karena selama proses pengunyahan terjadi pergerakan otot-otot pengunyahan, dengan gerakan otot ini mempunyai kemmpuan untuk dapat mendorong sekresi ludah terhadap rongga mulut sehingga terjadi self cleansing dalam mulut.

Tabel 7. Hasil analisis perbedaan efektivitas mengunyah buah apel dan buah semangka

\begin{tabular}{lccc}
\hline & $\begin{array}{c}\text { Mean } \\
\text { Sebelum } \pm \text { s.d }\end{array}$ & $\begin{array}{c}\text { Mean } \\
\text { Setelah } \pm \text { s.d }\end{array}$ & Sig.(2-tailed) \\
\hline $\begin{array}{l}\text { DI Setelah } \\
\text { Mengunyah Buah }\end{array}$ & $2.2 \pm 0.41$ & $1.2 \pm 0.29$ & \\
Apel & & & 0.000 \\
$\begin{array}{l}\text { DI Setelah } \\
\text { Mengunyah Buah }\end{array}$ & $2.4 \pm 0.45$ & $0.7 \pm 0.29$ & \\
Semangka & & & \\
\hline
\end{tabular}

Data pada tabel 7 dapat diketahui bahwa nilai mean debris indeks sesudah mengunyah buah apel adalah 1.2 dengan standar deviasi 0.29 . Sedangkan nilai mean sesudah mengunyah buah semangka adalah 0.7 dengan standar deviasi 0.29 dan nilai signifikasi atau sig. $(2$-tailed) $=0.000$. oleh karena nilai sig. $(2$-tailed) $<0.050$, maka hipotesis diterima. Dengan demikian dapat disimpulkan bahwa ada perbedaan efektivitas mengunyah buah apel dan buah semangka terhadap debris indeks siswa Surabaya.

Berdasarkan analisis data menunjukkan bahwa ada perbedaan antara mengunyah buah apel dan buah semangka terhadap penurunan nilai debris indeks pada siswa kelas VII SMP MIftahul Ulum Surabaya. Hasil tersebut menunjukkan bahwa kelompok mengunyah buah semangka lebih efektif dari pada mengunyah buah apel. Penelitian ini menunjukkan bahwa setelah mengunyah buah apel nilai debris indeks pada rongga mulut menjadi menurun, yang awalnya dengan katagori buruk menjadi sedang, tetapi buah semangka juga mengalami penurunan yang lebih efektif dibandingkan dengan buah apel, yang awalnya dengan katagori buruk menjadi baik. Semangka merupakan buah yang banyak disukai karena rasanya yang manis, mudah di dapat dan merupakan tanaman sumber vitamin, mineral, serat, dan mengandung enzim. Dalam semangka terdapat kadar 
air yang cukup tinggi yaitu sebesar $91,45 \mathrm{~g}$ dan terdapat kadar serat sebesar $0,4 \mathrm{~g}$ tiap $100 \mathrm{~g}$ daging buah semangka (Lusarnera dkk, 2016) Buah semangka merupakan buah yang berserat dan berair, dan memiliki kandungan air cukup banyak maka secara langsung dapat menghambat pembentukan plak pada gigi. Kandungan air yang cukup banyak dalam semangka membuat buah ini bisa menjadi pembersih alami bagi gigi dan mulut, sehingga bisa mengurangi bau mulut. Adanya kandungan air yang banyak pada buah semangka dapat menghilangkan plak yang sudah terbentuk.

\section{KESIMPULAN}

Berdasarkan hasil penelitian tentang perbedaan efektivitas mengunyah buah apel dan buah semangka dalam menurunkan nilai debris indeks pada siswa SMP Miftahul Ulum Surabaya, yaitu terdapat perbedaan efektivitas sesudah mengunyah buah apel mengalami penurunan sebesar 1.62, sedangkan mengunyah buah semangka mengalami penurunan sebesar 1.90. Dan kesimpulan dalam penelitian ini adalah terdapat perbedaan antara mengunyah buah apel dan buah semangka, buah semangka lebih efektiv dalam menurunkan nilai debris indeks.

\section{DAFTAR PUSTAKA}

Lusnarnera, R., Tendean, L. E. N., Gunawan, P. N., Sam, U., Manado, R., \& Indonesia, D. 2016 Pengaruh konsumsi semangka dalam menurunkan indeks debris pada anak usia 8-10 tahun. (Jurnal e-Gigi) Vol. 4, no 1 pp. 1-6. Manado: Universitas Sam Ratulangi Manado.

Nurasiki, C. A., \& Amiruddin, A. 2017. Efektifitas Mengunyah Buah Apel dan Buah Bengkoang Terhadap Penurunan Indeks Plak Pada Murid Sekolah Dasar. AcTion: Aceh Nutrition Journal, Vol. 2, no. 2 p. 80. https://doi.org/10.30867/action.v2i2.58

Penda, P. A. C., Kaligis, S. H. M., \& . J. 2015. Perbedaan Indeks Plak Sebelum Dan Sesudah Pengunyahan Buah Apel. E-GIGI, Vol. 3, no. 2. https://doi.org/10.35790/eg.3.2.2015.9631

Pratiwi D. 2009. GIGI SEHAT DAN CANTIK. Jakarta : "Irwan Suhanda”. Hal 19.

Prasetiowati, L. E., \& Wahyuni, S. 2016. Efektifitas Buah Semangka dan Jambu Biji Terhadap Nilai ( OHIS ) Pada Anak Usia 10-12 Tahun. Jurnal Analis Kesehatan, Vol. 5, no. 1 pp. 483-489. Tanjungkarang: Jurusan Keperawatan Gigi Politeknik Kesehatan Tanjungkarang. 